\title{
Excessive amount of lactose in the diet of two-week-old calves induces urinary protein changes
}

\author{
Alicja Dratwa-Chałupnik, Małgorzata Ożgo, Adam Lepczyński, Agnieszka Herosimczyk, and \\ Katarzyna Michałek \\ Department of Physiology, Cytobiology and Proteomics, Faculty of Biotechnology and Animal Husbandry, \\ The West Pomeranian University of Technology, Szczecin, Poland \\ Correspondence to: Alicja Dratwa-Chałupnik (alicja.dratwa-chalupnik@zut.edu.pl)
}

Received: 10 May 2016 - Revised: 12 September 2016 - Accepted: 19 September 2016 - Published: 13 October 2016

\begin{abstract}
The present paper was undertaken to analyse and identify urinary proteins that were significantly altered in urine of calves in response to short-term administration of milk replacer with lactose addition. We used 2-D electrophoresis combined with matrix-assisted laser desorption/ionisation and time-of-flight (MALDI-TOF) mass spectrometry. Of all spots analysed, four showed significantly decreased abundance: alpha-1-antiproteinase (A1AT), serotransferrin (TF), sex hormone-binding globulin (SHBG) and cytochrome P450 2E1 (CYP2E1). One displayed an increased abundance: adenosine triphosphate (ATP)-citrate synthase. The changes in abundance of SHBG and CYP2E1 proteins were caused by the direct effect of an oversupply of sugar, while A1AT, TF and ATP-citrate synthase showed altered abundance probably due to indirect effects. The results of this study confirmed that calves' urine is a very precious biological material to evaluate the renal function, and it may be valuable in veterinary and zootechnical diagnostics.
\end{abstract}

\section{Introduction}

Understanding biochemical processes that take place within a biological system requires recognising the highest number of proteins that are part of this system. These interactions have been examined widely in terms of proteomics recently. It is a branch of science that allows for large-scale analysis, identification, assessment of activity and localisation across multiple biological samples (e.g. cell, tissue, biological fluids; Chevalier, 2010). To date a large number of novel proteins have been identified including those that are characteristic of a specific physiological and pathological state of an animal. These proteins may help to gain insight into a novel mechanism underlying growth and development of animals (Jayasri et al., 2014; Wright et al., 2014). Proteomic analyses have been extensively used to identify diagnostic proteins that may be useful as markers for, for example, high animal productivity, assessment of the influence of environmental factors, and status of health and disease (Almeida et al., 2015; Janjanam et al., 2014; Kinkead et al., 2015).

As urine is a good source of information on renal function, it is therefore commonly used in diagnostic veterinary and human medicine. This biological fluid can be collected in large quantities in a non-invasive manner. Physiological urine contains only small amounts of proteins. It should be emphasised that increased urinary protein excretion occurs in both human and animal neonates (neonatal proteinuria) due to increased glomerular permeability and decreased tubular reabsorption (Schafer-Somi et al., 2005; Ojala et al., 2006; Ożgo et al., 2009). It is estimated that approximately $30 \%$ of all proteins excreted in urine are plasma proteins, whereas the remaining $70 \%$ are proteins derived from the kidney and urinary tract (Thongboonkerd and Malasit, 2005). Extensive effort has been made to find diagnostic urinary protein markers of renal function, especially the glomerulus and the renal tubules. Moreover, urinary proteomics has been extensively used to not only diagnose pathological processes that affect the excretory system but also to diagnose the functions of the other systems and other organs (Hong et al., 2007; Weissinger et al., 2007; Zimmerli et al., 2008).

Despite the fact that urine is quite easy to obtain, proteomic studies of urine in domestic animals are sparse (Pyo et al., 2003; Alhaider et al., 2012). Previously, Palviainen et 
al. (2012) found kidney-derived urinary protein biomarkers of acute kidney injury in sheep. Palviainen et al. (2012) postulate that these proteins may serve as a good markers for the early diagnosis of acute kidney injury in humans. The study of Lee et al. (2008) revealed a significant difference between urinary proteome of neonatal and adult rats.

The present paper was undertaken to analyse and identify urinary proteins that were significantly altered in urine of calves in response to short-term administration of milk replacer with lactose addition by using 2-D electrophoresis combined with matrix-assisted laser desorption/ionisation and time-of-flight (MALDI-TOF) mass spectrometry.

\section{Materials and methods}

The experiment was carried out on eight Polish HolsteinFriesian var. Black-and-White male calves in the second week of life. The use and handling of animals for this experiment was approved by the Local Commission of Ethics for the Care and Use of Laboratory Animals (Resolution No. $3 / 2010$ ). The body mass of calves averaged $38 \mathrm{~kg}$ on the 13th day of life. During the first three days of life, calves were fed with pooled colostrum and then from the 4th day to 13th day with milk replacer (Mlekovit Imupro ${ }^{\circledR}$, Polmass) containing $23 \%$ crude protein, $16 \%$ crude fat, $0.1 \%$ crude fiber, $45 \%$ lactose, $7.5 \%$ crude ash, $1.7 \%$ lysine, $0.42 \%$ methionine, $0.9 \%$ calcium and $0.7 \%$ phosphorus, twice daily in the amount of $10 \%$ of body weight per day. On the 13th day (during the evening feeding) and on the 14th day (during the morning feeding) monohydrate lactose (Pharma Cosmetic) in the amount of $1 \mathrm{~g} \mathrm{~kg}^{-1}$ of body weight was added into the milk replacer.

Blood plasma concentration of potassium was analysed using inductively coupled plasma optical emission spectrometry (ICP-OES) with a 2000 DV spectrometer (Perkin Elmer Inc) - the results are presented in the study of Dratwa-Chat upnik et al. (2016b). The blood glucose level was determined spectrophotometrically (Power-Wave Xa, Bio Tek) the results were previously published in the study of DratwaChałupnik et al. (2016a).

Urine samples were collected directly into the collection bags attached to the loins on the 13th day of life (before lactose administration) and on the 14th day of life (after second dose of lactose), $3 \mathrm{~h}$ before the evening feeding. The samples were centrifuged $\left(15 \mathrm{~min}\right.$, at $\left.4{ }^{\circ} \mathrm{C}, 3000 \mathrm{~g}\right)$ and then concentrated with $3 \mathrm{kDa}$ molecular weight cut-off filters AmiconU1tra (Millipore) and stored at $-80^{\circ} \mathrm{C}$.

\subsection{Two-dimensional electrophoresis (2-DE)}

Before 2-DE analysis, urine samples were desalted and cleaned using ReadyPrep ${ }^{\mathrm{TM}}$ 2-D Cleanup Kit (Bio-Rad). Two technical replicates were run for each urine sample.

Processed urine samples were dissolved in the lysis buffer containing $7 \mathrm{M}$ urea, $2 \mathrm{M}$ thiourea, $4 \% w / v$ CHAPS, $1 \% w / v$ dithiothreitol (DTT), 0.2\%w/v 3-10 ampholytes and $2 \mathrm{mM}$ tributyl phosphate (TBP). Urine protein samples $(100 \mu \mathrm{g})$ were applied to $\mathrm{pH} 4-7,7 \mathrm{~cm}$ NL ReadyStrip ${ }^{\text {TM }}$ IPG strips (Bio-Rad). Urinary proteins were focused according to the following procedure: (i) $250 \mathrm{~V}$ for $125 \mathrm{Vh}$, (ii) $500 \mathrm{~V}$ for $250 \mathrm{Vh}$, (iii) $1000 \mathrm{~V}$ for $500 \mathrm{Vh}$, (iv) linear increase to $5000 \mathrm{~V}$ for $1.5 \mathrm{~h}$, (v) $5000 \mathrm{~V}$ for $25000 \mathrm{Vh}$ using a Protean ${ }^{\circledR}$ IEF Cell (Bio-Rad). After IEF, the IPG strips were reduced with DTT in equilibration buffer $(6 \mathrm{M}$ urea, $0.5 \mathrm{M}$ Tris/ $\mathrm{HCl}, \mathrm{pH} 6.8$, $2 \% w / v$ sodium dodecyl sulfate (SDS), $30 \% w / v$ glycerol and $1 \% w / v$ DTT) for $15 \mathrm{~min}$ and then alkylated with iodoacetamide $(2.5 \% \mathrm{w} / v)$ for $20 \mathrm{~min}$ at ambient temperature. The second dimension was performed on $12 \%$ SDS polyacrylamide gels at $40 \mathrm{~V}$ for $1.5 \mathrm{~h}$ and then at $100 \mathrm{~V}$ for $13 \mathrm{~h}$ at $10^{\circ} \mathrm{C}$ using a Protean Plus ${ }^{\mathrm{TM}}$ Dodeca Cell ${ }^{\mathrm{TM}}$ electrophoretic chamber (Bio-Rad). After 2-DE separation, the gels were stained with CBB G-250 according to modified Kang method (Pink et al., 2010).

\subsection{Image analysis}

The gels were scanned using a GS- $800^{\mathrm{TM}}$ calibrated densitometer (Bio-Rad). Analysis of 2-D images was performed using a PDQuest Advanced gel analysis software version 8.0.1 (Bio-Rad). Image filtration, spot detection, intensity quantification, background substraction and spot matching between gels were performed automatically, followed by manual verification to remove false spots and to add missed spots. The spots present on at least three gels before and after administration of lactose were designated as expressed protein spots and were further analysed. The spot volume (expressed as a spot optical density - OD) was used as the parameter for quantifying protein abundance after normalisation based on the local regression model (LOESS). After normalisation, the volume of each spot was averaged for two replicates of each biological sample. The replicate gels used for match-set making had, at least, a correlation coefficient value of 0.8 . To measure the variability before and after administration of lactose, the coefficients of variation were calculated, and additionally for each protein spot the mean spot quantity value was calculated.

\subsection{Mass spectrometry}

The protein spots showing statistically significant differences were manually excised from the gels and decolourised by washing in buffer containing $25 \mathrm{mM} \mathrm{NH}_{4} \mathrm{HCO}_{3}$ in $5 \% v / v$ acetonitrile (ACN), followed by two washes with a solution of $25 \mathrm{mM} \mathrm{NH}_{4} \mathrm{HCO}_{3}$ in $50 \% v / v \mathrm{ACN}$. The gel pieces were dehydrated $(100 \% \mathrm{ACN})$, vacuum dried and incubated overnight with trypsin $\left(20 \mu \mathrm{L} \mathrm{spot}^{-1}\right.$ of $12.5 \mu \mathrm{g}$ trypsin $\mathrm{mL}^{-1}$ in $25 \mathrm{mM} \mathrm{NH} \mathrm{HCO}_{3}$; Promega, Madison, USA) at $37^{\circ} \mathrm{C}$. The resulting peptides were extracted with $100 \%$ ACN, combined with an equal volume of matrix solution $\left(5 \mathrm{mg} \mathrm{mL}^{-1}\right.$ CHCA, $0.1 \% v / v$ trifluoroacetic acid, $50 \% v / v$ ACN) and 


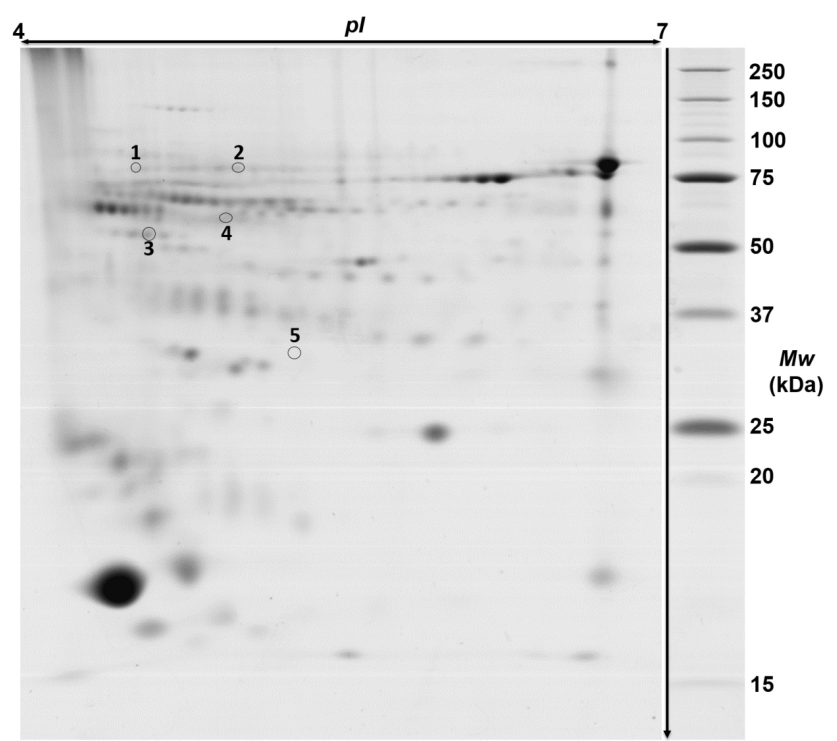

Figure 1. 2-DE map of the differentially abundant calves urine proteins. Presented 2-D gel was stained with Coomassie Brilliant Blue $\mathrm{G}-250 ; 100 \mu \mathrm{g}$ of proteins was applied on the IPG strip (7 cm, pH 4 7) for the first dimension, and the second dimension was performed on $12 \%$ SDS-PAGE gels. Spot numbers correspond to those in Table 1 .

loaded onto a MALDI-MSP AnchorChip ${ }^{\text {TM }}$ 600/96 plate (Bruker Daltonics, Germany). Peptide Mass Standard II was used (mass range 700-3200 Da, Bruker Daltonics) for calibration of the mass scale. Mass spectra were acquired in positive-ion reflector mode using a Microflex ${ }^{\mathrm{TM}}$ MALDITOF mass spectrometer (Bruker Daltonics, Germany). Peptide mass fingerprinting (PMF) data were compared to mammalian databases (SWISS-PROT; http://us.expasy.org/ uniprot/ and NCBI; http://www.ncbi.nlm.nih.gov/) with the aid of MASCOT search engine (http://www.matrixscience. com/). Search criteria included trypsin as an enzyme, carbamidomethylation of cysteine as a fixed modification, methionine oxidation as a variable modification, mass tolerance to $150 \mathrm{ppm}$ and a maximum of one missed cleavage site. The results were further validated by the MASCOT score (only statistically significant hits were applied) and sequence coverage.

\subsection{Statistics}

Significance of the differences in protein abundance pattern was confirmed during image analysis by one-sided Student's $t$ test using PDQuest Advanced gel analysis software.

\section{Results}

Approximately 209 protein spots were detected in each analysed gel, but only spots common for both experimental groups (132) were further analysed. Of these, four showed significantly decreased abundance: alpha-1-antiproteinase (A1AT), serotransferrin (TF), sex hormone-binding globulin (SHBG) and cytochrome P450 2E1 (CYP2E1). One showed an increased abundance: adenosine triphosphate (ATP)-citrate synthase (Table 1).

An example of a gel demonstrating the urine protein spots that differed in abundance is presented in Fig. 1.

In all calves, loose stools were observed with distinctive dark green colour after the second dose of lactose.

\section{Discussion}

Following lactose administration five urinary proteins were found differentially expressed. These proteins included alpha-1-antiproteinase, serotransferrin, sex hormone-binding globulin, ATP-citrate synthase and cytochrome P450 $2 \mathrm{E} 1$.

The decreased abundance of alpha-1-antiproteinase in urine of calves analysed in response to administration of lactose was accompanied by increased abundance of this protein in the plasma (Dratwa-Chałupnik et al., 2016a). Alpha1-antiproteinase belongs to the acute-phase proteins; its level in the blood plasma increases in response to inflammation or infection (Janciauskiene et al., 2011). Presumably due to the involvement of alpha-1-antiproteinase in response to diarrhea (observed in calves in response to the oversupply of lactose), its removal with the urine was decreased.

Serotransferrin, also known as beta-1 metal-binding globulin, is a major iron-binding protein in the blood plasma. It has a similar molecular weight as the albumin and can easily be filtered through the glomerular barrier (Cohen-Bucay and Viswanathan, 2012). It is considered as an indicator protein of glomerular damage in diabetic patients (Cohen-Bucay and Viswanathan, 2012; Zhao et al., 2014). In newborn humans and animals, an increased excretion of protein in the urine - neonatal proteinuria - is observed due to the higher permeability of the glomerular filtration barrier and limited efficiency of reabsorption in renal tubules (Calzada-García et al., 1996; Ożgo et al., 2009). It has been shown that the concentration of serotransferrin in the urine of neonatal rats was twice as high as the concentration of this protein in the urine of one-month-old rats (Calzada-García et al., 1996). Serotransferrin belongs to the negative acute phase protein family (Tîrziu, 2009). Graziadei et al. (1993) have shown that alpha1-antiproteinase (A1AT) regulates transferrin binding to its receptor by inhibiting it in a dose-dependent and competitive manner. These authors suggested that the inhibiting potential of A1AT could explain the pathophysiology of anaemia during the acute phase response to infections and malignant diseases. After administration of lactose to milk replacer, serotransferrin abundance in urine decreased, presumably in response to its reduced concentration in blood, modulated by increased abundance of alpha-1-antiproteinase in blood plasma in response to the addition of lactose (DratwaChałupnik et al., 2016a). 


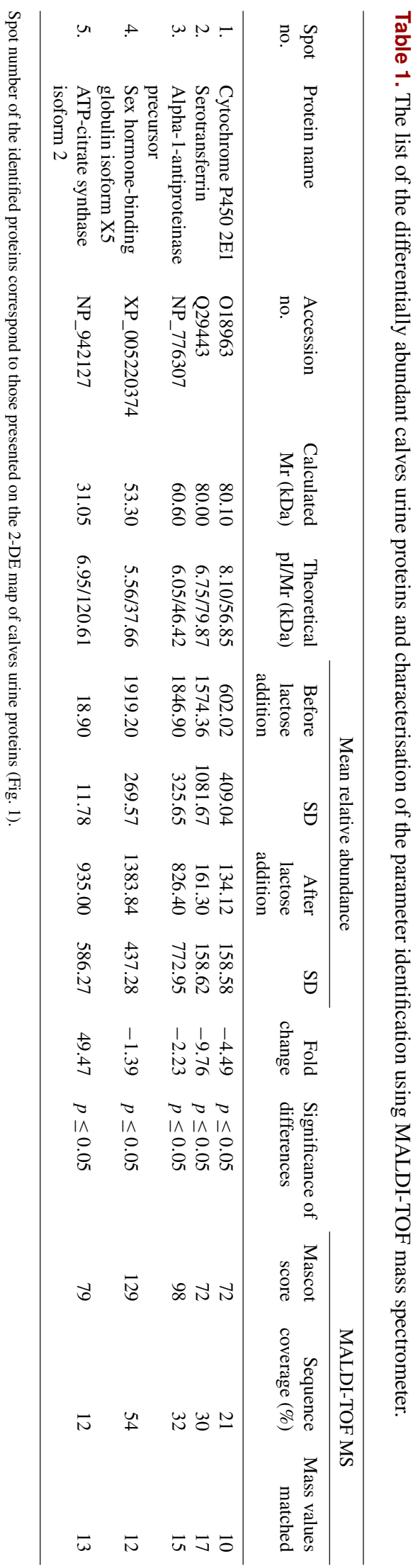

Sex hormone-binding globulin (SHBG) is another urine protein whose abundance was reduced in response to administration of lactose. This protein transports sex steroids and regulates their access to target tissues. Selva et al. (2007) demonstrated that glucose, sucrose and fructose reduced SHBG production by hepatocytes. The results of this study can indicate that an increased supply of lactose disaccharide may also reduce the synthesis of SHBG; consequently, removal of this protein in the urine is reduced. Only a slight increase in plasma glucose level was observed in calves $12 \mathrm{~h}$ after the second dose of lactose administration (DratwaChałupnik et al., 2016a).

A significant increase in the abundance of ATP-citrate synthase in urine was shown in the calves examined after administration of lactose. Increased removal of ATP-citrate synthase in the urine indicates that the filtered protein is not reabsorbed. The main reabsorption site of ATP-citrate synthase is proximal tubule, where it is carried out by the apical membrane $\mathrm{Na}$ /citrate cotransporter (Levi et al., 1991). Hypokalemia in rats, induced by a potassium-poor diet, stimulates the $\mathrm{Na}$ /citrate cotransporter; consequently, a reduction in urinary citrate excretion is observed (Levi et al., 1991). Melnick et al. (2000) did not observe any changes in the ATP-citrate synthase removal in urine in the infant rats, when potassium-poor diet was applied, despite the decrease in the concentration of this element in the plasma of these animals. A significant increase was observed in the concentration of potassium in the blood plasma of the experimental calves after administration of lactose to milk replacer formula (from 3.89 to $4.08 \mathrm{mmol} \mathrm{L}^{-1}$ ) - the results are presented in the study of Dratwa-Chałupnik et al. (2016b). Perhaps the increased $\mathrm{K}$ concentration in the blood plasma of calves examined contributed to increased urinary ATP-citrate synthase excretion. This is consistent with findings in our previous study conducted on older calves reporting no effect of lactose administration on the plasma potassium concentration or on the abundance of ATP-citrate synthase (Dratwa-Chałupnik et al., 2016b).

After administration of lactose into milk replacer, a decrease in the abundance of cytochrome P450 2E1 (CYP2E1) was observed in calves' urine. Cytochrome P450 2E1 plays a central role in the biotransformation of several precarcinogens, drugs and toxins. In rats during water deprivation, food supply increased the abundance of CYP2E1, while the addition of glucose instead of food inhibited the food-stimulated CYP2E1 abundance (Kim et al., 2006). The calves studied that did not have access to water were fed only with milk replacer formulation twice a day. The values of blood plasma glucose concentration increased from $4.27 \mathrm{mmol} \mathrm{L}^{-1}$ (before lactose administration) to $4.08 \mathrm{mmol} \mathrm{L}^{-1}$ (after lactose administration); however, these changes were not significantly relevant (Dratwa-Chałupnik et al., 2016a). The increased supply of glucose (derived from the lactose breakdown), as in the previously described experiment (Kim et al., 2006), was most likely the cause of decreased abundance of 
CYP2E1 in the urine of calves. The reason why glucose inhibits an abundance of cytochrome P450 2E1 is not clear.

It may be hypothesised that the lactose oversupply was the main factor that influenced the abundance level of the two proteins (sex hormone-binding globulin and cytochrome $\mathrm{P} 450$ 2E1), and the diarrhea may be the reason responsible for the observed alterations in the abundance of the remaining three proteins (alpha-1-antiproteinase, serotransferrin and ATP-citrate synthase). The results of the present and previous studies clearly indicate that excessive amount of lactose in a diet of calves induces changes not only in blood plasma proteins (Dratwa-Chałupnik et al., 2016a) but also in urinary proteins.

Establishment of the two-dimensional maps reflecting characteristic patterns of urinary proteins of domestic animals might be useful for designing further proteomic studies aimed at elucidating the patterns of renal adjustments to various pathophysiological factors including environmental stressors. Results of such studies may allow the testing of urine samples for proteins that are produced while having a particular disease.

\section{Data availability}

The original data are available upon request to the corresponding author.

Acknowledgements. This work was supported by scientific grant from National Centre of Science, Poland, 2011-2013 (project no. N N311 016239).

Edited by: M. Mielenz

Reviewed by: B. Kuhla and one anonymous referee

\section{References}

Alhaider, A. A., Bayoumy, N., Argo, E., Gader, A. G., and Stead, D. A.: Survey of the camel urinary pro-teome by shotgun proteomics using a multiple database search strategy, Proteomics, 12, 3403-3406, 2012.

Almeida, A. M., Bassols, A., Bendixen, E., Bhide, M., Ceciliani, F., Cristobal, S., Eckersall, P. D., Hollung, K., Lisacek, F., Mazzucchelli, G., McLaughlin, M., Miller, I., Nally, J. E., Plowman, J., Renaut, J., Rodrigues, P., Roncada, P., Staric, J., and Turk, R.: Animal board invited review: advances in proteomics for animal and food sciences, Animal, 9, 1-17, 2015.

Calzada-García, J. A., Pérez González, M. N., Benito-Andrés, F. J., Morales García, L. J., Cabezas, J. A., and Sánchez-Bernal, C.: Evaluation of patterns of urinary proteins by SDS-PAGE in rats of different ages, Mech. Ageing Dev., 87, 1-13, 1996.

Chevalier, F.: Highlights on the capacities of "Gel-based" proteomics, Proteome Sci., 8, 23, doi:10.1186/1477-5956-8-23, 2010.

Cohen-Bucay, A. and Viswanathan, G.: Urinary markers of glomerular injury in diabetic nephropathy, Int. J. Nephrol., 2012, 146987, 11 pp., doi:10.1155/2012/146987, 2012.
Dratwa-Chałupnik, A., Ożgo, M., Herosimczyk, A., Lepczyński, A., and Michałek, K.: Lactose rich milk replacer modifies the proteome of blood plasma in two-week-old calves, Turk. J. Vet. Anim. Sci., 40, 21-27, 2016a.

Dratwa-Chałupnik, A., Ożgo, M., and Michałek, K.: Water and electrolyte management in calves before and after administration excess of lactose, Med. Weter., 72, 231-236, $2016 \mathrm{~b}$.

Graziadei, I., Kaserbacher, R., Braunsteiner, H., and Vogel, W.: The hepatic acute-phase proteins x1-antitrypsin and x2macroglobulin inhibit binding of transferrin to its receptor, Biochem. J., 290, 109-113, 1993.

Hong, C. S., Cui, J., Ni, Z., Su, Y., Puett, D., Li, F., and Xu, Y.: A computational method for prediction of excretory proteins and application to identification of gastric cancer markers in urine, Blood, 109, 5511-5515, 2007.

Janciauskiene, S. M., Bals, R., Koczulla, R., Vogelmeier, C., Köhnlein, T., and Welte, T.: The discovery of $\alpha 1$-antitrypsin and its role in health and disease, Respir. Med., 105, 1129-1139, 2011.

Janjanam, J., Singh, S., Jena, M. K., Varshney, N., Kola, S., Kumar, S., Kaushik, J. K., Grover, S., Dang, A. K., Mukesh, M., Prakash, B. S., and Mohanty, A. K.: Comparative 2D-DIGE proteomic analysis of bovine mammary epithelial cells during lactation reveals protein signatures for lactation persistency and milk yield, PLoS One, 9, e102515, doi:10.1371/journal.pone.0102515, 2014.

Jayasri, K., Padmaja, K., and Eswar Prasad, P.: Proteomics in Animal Health and Production, IOSR-JAVS, 7, 50-56, 2014.

Kim, Y. C., Lee, I., Kim, S. G., Ko, S. H., Lee, M. G., and Kim, S. H.: Effects of glucose supplementation on the pharmacokinetics of intravenous chlorzoxazone in rats with water deprivation for 72 h, Life Sci., 79, 2179-2186, 2006.

Kinkead, R. A., Elliott, C. T., Cannizzo, F. T., Biolatti, B., and Mooney, M. H.: Proteomic identification of plasma proteins as markers of growth promoter abuse in cattle, Anal. Bioanal. Chem., 407, 4495-4507, 2015.

Lee, R. S., Monigatti, F., Lutchman, M., Patterson, T., Budnik, B., Steen, J. A., Freeman, M. R., and Steen, H.: Temporal variations of the postnatal rat urinary proteome as a reflection of systemic maturation, Proteomics, 8, 1097-1112, 2008.

Levi, M., McDonald, L. A., Preisig, P. A., and Alpern, R. J.: Chronic $\mathrm{K}$ depletion stimulates rat renal brush-border membrane Nacitrate cotransporter, Am. J. Physiol., 261, F767-773, 1991.

Melnick, J. Z., Preisig, P. A., Alpern, R. J., and Baum, M.: Renal citrate metabolism and urinary citrate excretion in the infant rat, Kidney Int., 57, 891-897, 2000.

Ojala, R., Ala-Houhala, M., Harmoinen, A. P., Luukkaala, T., Uotila, J., and Tammela, O.: Tubular proteinuria in pre-term and full-term infants, Pediatr. Nephrol., 21, 68-73, 2006.

Ożgo, M., Skrzypczak, W. F., Drzeżdżon, D., Lepczyński, A., Dratwa-Chałupnik, A., Michałek, K., and Herosimczyk, A.: Urinary excretion of low molecular weight proteins in goats during the neonatal period, J. Physiol. Pharmacol., 60, 119-125, 2009.

Palviainen, M., Raekallio, M., Rajamäki, M. M., Linden, J., and Vainio, O.: Kidney-derived proteins in urine as biomarkers of induced acute kidney injury in sheep, Vet. J., 193, 287-289, 2012.

Pink, M., Verma, N., Rettenmeier, A. W., and Schmitz-Spanke, S.: CBB staining protocol with higher sensitivity and mass spectrometric compatibility, Electrophoresis, 31, 593-598, 2010. 
Pyo, J., Hwang, S. I., Oh, J., Lee, S. J., Kang, S. C., Kim, J. S., and Lim, J.: Characterization of a bovine pregnancy-associated protein using two-dimensional gel electrophoresis, N-terminal sequencing and mass spectrometry, Proteomics, 3, 2420-2427, 2003.

Schafer-Somi, S., Bar-Schadler, S., and Aurich, J. E.: Proteinuria and immuneglobulinuria in neonatal dogs, Vet. Rec., 157, 378382, 2005.

Selva, D. M., Hogeveen, K. N., Innis, S. M., and Hammond, G. L.: Monosaccharide-induced lipogenesis regulates the human hepatic sex hormone-binding globulin gene, J. Clin. Invest., 117, 3979-3987, 2007.

Thongboonkerd, V. and Malasit, P.: Renal and urinary proteomics: current applications and challenges, Proteomics, 5, 1033-1042, 2005.

Tîrziu, E.: Acute-phase proteins in immune response, Lucrări ştiinţifice Medicina? veterinară, XLII, 329-339, 2009.

Weissinger, E. M., Schiffer, E., Hertenstein, B., Ferrara, J. L., Holler, E., Stadler, M., Kolb, H. J., Zander, A., Zürbig, P., Kellmann, M., and Ganser, A.: Proteomic patterns predict acute graft-versus-host disease after allogeneic hematopoietic stem cell transplantation, Blood, 109, 5511-5519, 2007.
Wright, E. P., Partridge, M. A., Padula, M. P., Gauci, V. J., Malladi, C. S., and Coorssen, J. R.: Top-down proteomics: enhancing 2D gel electrophoresis from tissue processing to high-sensitivity protein detection, Proteomics, 14, 872-889, 2014.

Zhao, M., Li, M., Li, X., Shao, C., Yin, J., and Gao, Y.: Dynamic changes of urinary proteins in a focal segmental glomerulosclerosis rat model, Proteome Sci., 12, 42, doi:10.1186/1477-595612-42, 2014.

Zimmerli, L. U., Schiffer, E., Zurbig, P., Good, D. M., Kellmann, M., Mouls, L., Pitt, A. R., Coon, J. J., Schmieder, R. E., Peter, K. H., Mischak, H., Kolch, W., Delles, C., and Dominiczak, A. F.: Urinary proteomic biomarkers in coronary artery disease, Mol. Cell. Proteomics, 7, 290-298, 2008. 